ОСВІТНЯ ТА ПРОСВІТНИЦЬКА ДІЯЛЬНІСТЬ ЧИНУ

НАЙСВЯТІШОГО ІЗБАВИТЕЛЯ СЕРЕД УКРАЇНСЬКОЇ ДІАСПОРИ КАНАДИ У ПЕРШІЙ ПОЛ. ХХ СТ.

\title{
TEACHING AND EDUCATIONAL ACTIVITY OF REDEMPTORIST FATHERS (CONGREGATION OF THE MOST HOLY REDEEMER) IN THE UKRAINIAN DIASPORA OF CANADA IN THE FIRST HALF OF THE 20TH CENTURY
}

У статті висвітлено освітню та просвітницьку діяльність отців Чину Найсвятішого Ізбавителя (ЧНI) Української греко-католицької черкви в українській діаспорі Канади у 1909-1956 рр. Розглянуто історію створення східної гілки ЧНІ, зокрема проаналізовано роль бельгійського місіонера о. Ахіла Деляре, який у 1906 р. змінив латинський обряд на східний для праці серед українців Канади. Звертається увага на вклад митрополита Андрея (Шептицького) у появу ЧНІ у Канаді, а також роль, яку відіграв ЧНІ у створенні єпархіальних структур УгКЦ у Канаді. у дослідженні підкреслено, що від самого початку своєї праці у Канаді ченці-редемптористи зайнялися не лише духовною опікою українців, але й зробили значний внесок у розвиток їхньої освіти. У статmі проаналізовано навчальні заклади, що були створен за безпосередньої ініціативи ЧНІ, а також за підтримки та безпосередньої участі членів ордену. Розглянуто також співпрацю ЧН з іншими орденами УГКЦ та РКЦ у галузі освіти у Канаді, у тому числі з монахинями ордену Сестер служебниць Непорочної Діви марії та Братами християнських шкіл. Авторка також охарактеризувала та проаналізувала роль отців ЧНІ у становленні та розвитку української періодики на прикладі часописів, які видавав орден: двомовного місячника «Голос Спасителя» та квартальника «Логос». У статті акцентовано, що періодика, видана за участю отиів ЧНІ, орієнтувалася на широке коло читачів, тому спектр публікацій теж був доволі широким: від історії і подій церковного та суспільного життя до морально-етичного виховання вірних УГКЦ. Авторів часописів серед іншого цікавило і питання релігійної освіти українців Канади. Cтаття містить нову та важливу інформацію про роль ордену редемптористів східного обряду в освітньому та просвітницькому житті українців у Канаді. Автором зауважено, що саме така діяльність отців позитивно вплинула на збереження української культури та історичної пам'яті та протидіяла асиміляції українського населення й стала основою для самоідентифрікації української еміграції у Канаді. Ключові слова: освіта, УГКЦ, Канада, ЧНІ, школа, колегія, коледж, друкарня.
The article highlights the teaching and educational activity of fathers of the Congregation of the Most Holy Redeemer (CSsR) of the Ukrainian Greek Catholic Church in the Ukrainian diaspora of Canada in 1909-1956. The author describes the history of the foundation of the Eastern Branch of the CSsRand, the role of the father Achilles Delaere, a Belgian Redemptorist in this process. Father Achilles Delaere adopted the Byzantine-Ukrainian Rite and spent 35 years among Ukrainian Catholic immigrants in Western Canada and was instrumental in establishing the Province. It is substantiated, that Metropolitan Andrey Sheptytsky's contribution to the emergence of the CSsR in Canada was enormous, as well as the role of CSsR in establishing the diocesan structures of the UGCC in Canada. It is emphasized that from the very beginning of their work in Canada, the Redemptorist monks were not only engaged in the spiritual care of Ukrainians but also made a significant contribution to the development of their education. The article focuses on the educational institutions that were created under the direct initiative of the CSSR or with the support and direct participation of members of the Order in the institutions' life. The cooperation of the Redemptorists with other orders of the UGCC and the RCC in the field of education in Canada, including the Sisters Servants of Mary Immaculate the Brothers of the Christian Schools is determined. The author also describes and analyzes the role of the CSsR fathers in the formation and development of Ukrainian periodicals on the example of journals published by the order: the bilingual monthly magazine "Voice of the Savior" and the quarterly magazine "Logos". They also produced educational bulletins, books, pamphlets, and audio-visual resources. The article contains new and important information about the role of the Redemporists in teaching and educational life of Ukrainians in Canada. The author states that such activity of the priests had a positive effect on the preservation of Ukrainian culture and historical memory and counteracted the assimilation of the Ukrainian population and became the basis for self-identification of Ukrainian emigration in Canada.

Key words: education, UGCC, Canada, CSsR, school, college, printing house.
Національного університету

«Львівська політехніка»
Постановка проблеми у загальному вигляді. Чин Найсвятішого Ізбавителя (лат. Congregatio Sanctissimi Redemptoris) або Згромадження редемптористів заснував у 1732 році на півдні Італії адвокат Альфонс Ліґуорі (1696-1787). У 1749 р. чин затвердив глава Римо-католицької церкви Папа Римський Бенедикт XIV (1675-1758). Головну мету чину його засновник вбачав у духовному служінні та проповідницькій місії серед найбільш убогих прошарків суспільства [3, с. 103-105].
Українська гілка редемптористів постала стараннями митрополита Андрея (Шептицького) (1865-1944), який 1913 року прийняв членів ордену 3 Бельгії, які прийняли східний обряд, в Уневі біля Перемишлян, що на Львівщині та у Збоїськах під Львовом [9, с. 101-105].

Аналіз останніх досліджень і публікацій. Проблемою становлення української освіти в Канаді і роллю УГКЦ у цьому процесі, зокрема й чернечих згромаджень, займалися М. Марунчак, 
О. Ковальчук, І. Машкова, І. Франків, О. Сухобокова, І. Руснак, І. Шкварок, П. Божик та інші.

Значний внесок у дослідження та вивчення просвітницької діяльності чоловічих греко-католицьких монаших згромаджень у Канаді, у тому числі ЧНІ, зробили вчені І. Бала, Р. Хом'як, І. Патарак, М. Боровик, Н. Марченко та інші.

Вагомий вклад у дослідження та вивчення історії та просвітницької діяльності згромадження ЧНІ у Канаді зробив Пауль Лавендюр - автор фундаментального нарису про орден.

Певний доробок у царині цієї тематики належить і сестрам ССНДМ. Зокрема, цінні спогади про їхню співпрацю 3 отцями ЧНІ у просвітницькій діяльності серед українців у Канаді залишили сестри ССНДМ (Є. Кассіян, А. Ленкевич, А. Левчишин, А.Мельник, К. Попович та інші).

Згадані дослідження акцентують увагу на історії створення східної гілки редемптористів та дають змогу скласти певне уявлення про їхню працю в галузі освіти українців у Канаді, проте не повністю висвітлюють роль згромадження у становленні та розвитку шкільництва в українській діаспорі цієї країни.

Метою цього дослідження є висвітлення історії просвітньої діяльності Чину Найсвятішого Ізбавителя в Канаді, аналіз їхньої педагогічної праці та видавничої діяльності.

Виклад основного матеріалу. Предтечею греко-католицької гілки редемптористів став бельгійський місіонер о. Ахіл Деляре, який у 1906 р. змінив латинський обряд на східний для праці серед українців Канади. Отець Ахіл розпочав свою місію 11 жовтня 1899 року 3 міста Брендона у провінції Манітоба, куди редемптористів запросив римо-католицький архієпископ Сен-Боніфасу ЛуїФіліп-Аделяр Лянжевен (1855-1915) для праці серед емігрантів. Ахіл Деляре, окрім інших громад, обслуговував духовно й українську. Праця о. Деляре припала на період активної колонізації канадських провінцій українцями, які відчували гострий брак священників своєї церкви. У 1901 році працю бельгійського редемпториста високо оцінив секретар митрополита Андрея Шептицького о. Василь Жолдак, який за дорученням митрополита відвідав Канаду. Задоволений працею Ахіла Деляре, Василь Жолдак звернувся до архієпископа Лянжевена 3 проханням призначити його душпастирем українських поселенців округу Йорктона, де серед 10 тис. католиків майже 7 тис. були україномовними [9, с. 55]. Після отримання відповідного дозволу, у 1901-1904 рр. Ахіл Деляре періодично відвідував новий округ, а 312 січня 1904 року залишився в Йорктоні для постійної праці. Працю серед українців Канади о. Ахіла ускладнював латинський обряд, який насторожував українців, а ще більше погане знання української мови. 3 огляду на це він звернувся до Папи
Римського за дозволом перейти із латинського на східний (візантійський) обряд, що й відбулося у 1906 році з благословення Папи Пія Х. Після цього о. Деляре вирушив до Вінніпега, де завдяки ченцям василіанам вивчив східний обряд та українську мову. Праця Ахіла Деляре була настільки успішною, що зорганізовані ним громади потребували все більше священників. На його прохання до Канади вислали інших редемптористів: Г. Бульса, Н.М. Декампа, К. Тешира та Л. Боского, які вже перед тим вивчали східний обряд та українську мову у Галичині $[10$, с. 81$]$.

У 1910 р. митрополит Андрей Шептицький 3 нагоди Євхаристійного конгресу у Монреалі відвідав Канаду. Митрополит використав цю нагоду, щоб здійснити перші відвідини місцевих громад греко-католиків. Він, зокрема, відвідав українські поселення, де працювали о. Деляре та його співбрати. Праця редемптористів настільки вразила митрополита, що він вирішив запросити бельгійських священників розпочати подібну місійну працю й на Західній Україні, що в майбутньому дало змогу поповнювати ряди священнослужителів ордену в Канаді за рахунок еміграції [7, с. 120-121].

Ахіл Деляре відіграв також важливу роль і у призначенні першого єпископа для грекокатоликів Канади. Зокрема, у 1912 р., перебуваючи у Римі, він повідомив Папу Римського Пія $\mathrm{X}$ (1835-1914) про гостру потребу єпископа для українців-греко-католиків у Канаді. Після призначення єпископом Никити (Будки) (1877-1949) 18 березня о. Ахіл звернувся до нього із проханням про заснування у Канаді провінції Чину редемптористів візантійсько-слов'янського обряду. Його прохання задовольнили і вже 2 серпня 1913 р. о. Деляре розпочав будівництво у Йорктоні першого монастиря українських редемптористів [1, с. 566].

Від самого початку своєї праці у Канаді ченціредемптористи зайнялися не лише духовною опікою українців, але й зробили значний внесок у розвиток їхньої освіти. Ще у 1909 р. у меморіалі до папського легата у Канаді, з приводу першого пленарного собору у Квебеку, о. Деляре зазначав, що потрібно «створити низку католицьких українських шкіл і їх управління передати українським монахиням: Сестрам служебницям Непорочної Діви Марії, Сестрам чину св. Василія Великого чи іншим» [1, с. 566]. Свої пропозиції він повторив 23 серпня 1914 р. під час посвячення церкви Матері Божої Неустанної Помочі у Йорктоні єпископові Никиті (Будці), зазначивши, що при церкві «потрібно негайно створити школу» [10, с. 81].

Турбуючись про стан освіти серед українцівкатоликів ЧНІ доклали всіх зусиль, щоб у 1915 р. до Йорктона прибули сестри ССПДМ. Редемптористи опікувалися ними і допомогли у заснуванні школи для дівчат при церкві Матері Божої Неустанної Помочі, що згодом переросла в ака- 
демію. Навчальний заклад відкрив свої двері на початку 1917 року як початкова школа та сиротинець. У 20-тих роках XX ст. значно зросла кількість дітей і школа стала 8-ступеневою. У 1928 р. вона була відзначена провінційним інспектором департаменту освіти за успішну працю вчителів. У 1932 р. «Школу Пресвятого Серця» перетворено на середню [10, с. 253]. У 1934 р. навчальний заклад мав уже 10 ступенів. У 1945 р. школу поділили: учениці 1-8 ступенів перейшли до окремої школи при згаданій церкві, організацією якої займалися ігумени ЧНІ Степан Бахталовський та Григорій Шишкович, а учениці 9-12 ступенів почали навчатися у середній школі, що отримала назву «Академія Пресвятого Серця» [1, с. 566].

Післяуспішного створення навчального закладу для дівчат у Йорктоні, у 1918 р. редемптористи Н.М. Декамп та Л. Боский вирішили заснувати й вищу школу для хлопців. Ініціативу підтримав і єпископ Никита (Будка) [8, с. 66]. Оскільки у Канаді тоді не було жодного українського чоловічого згромадження, яке б могло забезпечити школу вчителями, то редемптористи звернулися за допомогою до римо-католицького архієпископа Торонто Ніла Макніла (1851-1934), який дуже прихильно ставився до українських емігрантів, а також Братів християнських шкіл (БХШ) РКЦ у Торонто. Завдяки старанням товариства і підтримці українських емігрантів Брати християнських шкіл прибули до Йорктауна у 1919 р. і заснували школу-інтернат для українських хлопців. Серед перших учителів були БХШ: брат Ансберт М. Шіді, брат Станіслав Дж. Орейлі і брат Джеймс Дж. Валікет [10, с. 90].

ще на етапі творення школи виникла дискусія між ЧНІ та БХШ щодо мови викладання: редемптористи пропонували створити українську школу, де англійську мали викладати як один із предметів, а БХШ наполягали на створенні англійської школи [9, с. 94]. Попри дискусії, 4 жовтня 1920 р. колегія св. Йосиора почала працювати. Тут навчалися студенти з різних куточків Канади та навіть США. Роботу навчального закладу контролював відділ освіти провінції, який щорічно надсилав своїх інспекторів. Навчання тривало 12 років. Учні вивчали українську, англійську, фрранцузьку, німецьку та латинську мови. Велику увагу присвячували також книговодству, стенографрії та спорту. Релігію та українознавство у певні періоди у колегії викладали редемптористи, зокрема Й. Пуляк, В. Шумей, І. Перейма, К. Лотоцький, М. Сирник, П. Криворучка. Впродовж перших двадцяти років існування випускниками колегії стали близько 1000 юнаків [8, с. 37].

У 1952 р. шкільна влада провінції Саскачеван дозволила Академії Пресвятого Серця і колегії св. Йосифа ввести як один із обов'язкових предметів до 9-12 ступенів українську мову. У обох навчальних закладах ченці ЧНІ, окрім духовної опіки, також викладали українську мову, літературу та історію України [1, с. 567].

ЧНІ також спричинився до заснування школи у Айтуні (Саскачеван). Редемптористи створили свій осередок у цій місцевості у жовтні 1919 р. Уже наступного 1920 року о. Деляре запросив до Айтуни сестер ССПДМ, які за підтримки ЧНІ у 1938 р. збудували великий сиротинець св. Анни, при якому постала 8-річна школа. Редемптористи допомагали ССпДМ у праці у сиротинці та школі, зокрема були катехитами та сповідниками $[8$, c. 66].

У 1941 р. ЧНІ придбав землю поблизу Робліна (Манітоба), де заснував коледж св. Володимира, який став навчальним закладом для самих редемптористів - їхньою малою семінарією [4, с. 367]. Навчальний заклад для власного вжитку - семінарію Пренепорочної Діви Марії ЧНІ заснували й на сході Канади, у Ватерфорді (Онтаріо) у 1947 р. [9, с. 182]. Оскільки вона не відповідала всім потребам, то у 1952 р. ЧНІ створили фрілію семінарії Пренепорочної Діви Марії у Медоввейл (Онтаріо) [1, с. 215].

Чин редемптористів, окрім діяльності на ниві освіти, залишив визначний слід у історії друкованого слова в українській діаспорі Канади. 3 квітня 1923 р. у Йорктоні почав виходити журнал ЧНІ «Голос Ізбавителя» [2, с. 102-103]. Його редактором був о. Йосип Бала, українець за походженням, який став членом бельгійського чину в 1913 році. Часопис видавали до березня 1928 року [7, с. 125]. У 1933 р. під новою назвою - «Голос Спасителя» його видання відновив новий редактор о. Іван Бала.

Місячник «Голос Спасителя» був двомовним: половину його займали україномовні публікації, решту - англомовні. Оскільки це був друкований орган ЧНІ у Канаді, то авторами публікацій видання були переважно самі редемптористи. Місячник орієнтувався на широке коло читачів, тому спектр публікацій теж був доволі широким: від історії і подій церковного та суспільного життя до морально-етичного виховання вірних УГКЦ. Авторів часопису, зокрема, цікавило і питання релігійної освіти українців Канади. Позаяк видавали місячник редемптористи, то, природно, що в ньому здебільшого друкувалися матеріали, в яких йшлося про духовні освітні заклади цього чину, такі як Колегія св. Володимира в Робліні, Колегія св. Йосифра в Йорктоні та ін. [5, с. 317-328].

ще одним виданням ЧНІ був квартальник «Логос», що з'явився в 1950 році в м. Ватерфрорді (поблизу Торонто), а з 1956 року виходив у м. Йорктоні (Саскачеван). Його видавала колегія профресорів семінарії ЧНІ. Квартальник був призначений для богословів та науковців. Засновником і першим редактором журналу став перший митрополит Української греко-католицької церкви в Канаді Максим Германюк (1956-1992). Пізніше 
квартальник редагували Володимир Маланчук, Михайло Гринчишин та Степан Шавель. Про високий науковий рівень часопису свідчить його авторський склад. Часопис постійно друкував праці таких відомих науковців, літературознавців, журналістів та громадських діячів, як Микола Андрусяк, Євген Вертипорох, Володимир Дорошенко, Олександр Домбровський, Григорій Лужницький, Ісидор Нагаєвський, Іриней Назарко, Олександр Оглоблин, Микола Чубатий та ін.

Оскільки «Логос» був богословським виданням, чільне місце на його сторінках посідали матеріали теологічного характеру. Проте друкувалося чимало матеріалів з історії, фрілософії, культурології, літературознавства та мистецтвознавства. Хвилювало авторів часопису і питання освіти українців Канади. Тут також постійно друкувалися матеріали, в яких йшлося про духовні освітні заклади, зокрема, матеріали присвячені навчанню в Колегії св. Володимира в Роблині (Манітоба), Академії в Анкастері (Онтаріо), Малій семінарії в Кастель-Гандольфо (неподалік Рима), Духовній семінарії у Вашингтоні, Григоріанському університету в Римі, а також відкриттю українських студій у Гарвардському університеті та ін. [6, с. 478-488].

З 1949 р. ЧНІ організував культурні та релігійні радіопрограми на йорктонському радіо [9, с. 187].

Висновки. Варто зазначити, що чНІ відіграв важливу роль не лише для становлення УГКЦ у Канаді, але й зробив вагомий внесок у розвиток української освіти, починаючи з першої хвилі еміграції до цієї країни. Завдяки праці ченців ЧНІ у Канаді засновано низку різнотипних освітніх закладів та часописів. Видавнича діяльність редемптористів сприяла згуртуванню української молоді, заохочувала її до вивчення рідної мови та літератури, збереження традицій. Такі кроки позитивно вплинули на збереження української культури та історичної пам'яті, протидіяли асиміляції українського населення та стали міцною основою для самоідентифрікації української еміграції у Канаді.

\section{БІБЛІОГРАФІЧНИЙ СПИСОК:}

1. Альманах Торонтської Єпархії. Торонто, 1964. $752 \mathrm{c}$

2. Боровик М. Українсько-канадська преса та її значення для української меншини в Канаді. Мюнхен, 1977. 344 с.

3. Католическая энциклопедия / редкол.: В.Л. Задворный и др. Москва, 2011. Т. 4. 1960 с.

4. Ковч-Баран А.-М. Українські католицькі церкви Вінніпезької архієпархії. Саскатун, 1991. 460 с.

5. Марченко Н. Українські періодичні видання чернечих орденів Греко-католицької церкви в Канаді в другій половині XX століття. Наукові записки Національного університету «Острозька академія». Історичні науки. 2009. Вип. 14. С. 317-328.

6. Марченко Н. Канадський квартальник «Логос»: структура та зміст видання. Наукові записки Національного університету «Острозька академія». Історичні науки. 2008. Вип. 11. С. 478-488.

7. Патарак І. Чин отців Редемптористів у громадсько-релігійному житті українців у Канаді. Наукові записки Національного університету «Острозька академія». Історичні науки. 2008. Вип. 11. С. 119-127.

8. Пропам'ятна книга 3 нагоди Золотого Ювілею Поселення Українського Народу в Канаді, 1891-1941. Йорктон (Саскачеван), 1941. 338 с.

9. Paul Laverdure, Redemption and ritual: the eastern-rite Redemptorists of North America 1906-2006. Yorkton, 2007. 421 p.

10. Popowich $\mathrm{C}$. To serve is to love. The Canadian story of the Sisters Servants of Marry Immaculate. Toronto, 1971. 355 p. 